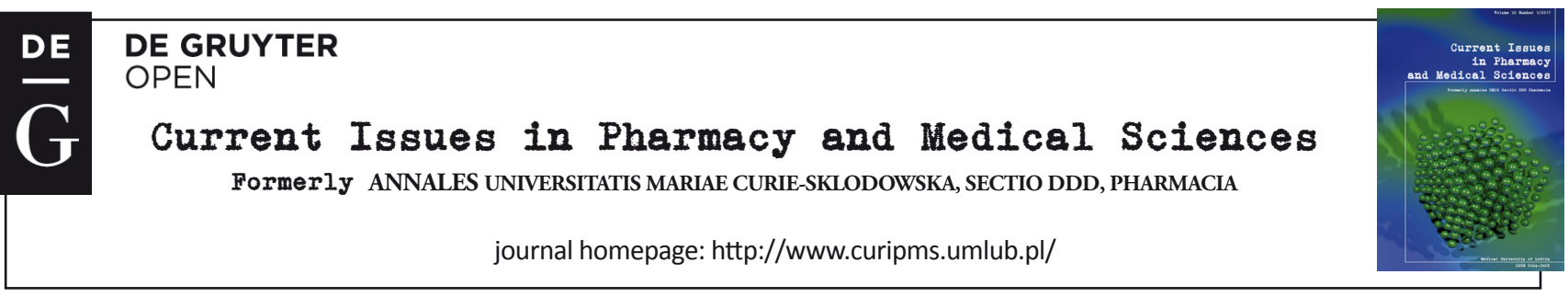

\title{
The condition of oral mucosa in the elderly (over 65 years) of Lublin
}

\author{
Katarzyna Kaminska-Pikiewicz, Renata Chalas*, Teresa Bachanek
}

Chair and Department of Conservative Dentistry and Endodontics, Medical University of Lublin, Karmelicka 7, 20-081 Lublin, Poland

\begin{tabular}{|c|c|}
\hline ARTICLE INFO & ABSTRACT \\
\hline $\begin{array}{l}\text { Received } 12 \text { April } 2017 \\
\text { Accepted } 25 \text { April } 2017\end{array}$ & $\begin{array}{l}\text { Mucous membrane defense mechanisms are impaired with age, both immunologically } \\
\text { and physically. This decreases oral mucosa regenerative capability and results in greater }\end{array}$ \\
\hline $\begin{array}{l}\text { Keywords: } \\
\text { elderly, } \\
\text { oral mucosa, } \\
\text { nursing homes. }\end{array}$ & $\begin{array}{l}\text { susceptibility to injuries and microbial and fungal colonization. Pathological changes of } \\
\text { the mucous membrane should be diagnosed and treated early, as some may develop into } \\
\text { cancerous changes. Therefore, regular dental check-ups are essential, especially in old age. } \\
\text { The aim of the study was to assess the condition of the oral mucosa in seniors residing in } \\
\text { either Lublin Nursing Homes (LNH) or in home care. The study was conducted among } \\
240 \text { people over the age of } 65: 117 \mathrm{LNH} \text { residents and } 123 \text { seniors living independently. } \\
\text { The assessment of oral mucosa was conducted via clinical examination so as to see } \\
\text { evidence of pathological change. On the base of the performed examination, pathological } \\
\text { changes of the oral mucosa were observed in } 43.59 \% \text { of all LNH residents and in } 34.96 \% \\
\text { of all seniors living in home care (independently). In both groups, atrophic glossitis, } \\
\text { candidiasis (in susp.) and stomatitis prothetica were most frequently noted. Hence, it can } \\
\text { be said that the condition of the oral mucosa of the examined seniors from Lublin is } \\
\text { unsatisfactory. }\end{array}$ \\
\hline
\end{tabular}

\section{INTRODUCTION}

Oral mucosa in the elderly undergoes extensive physiological changes. This is seen in the masticatory, lining and specialized mucosa. What is more, it becomes less elastic because of the decrease of elastic fibers, and it is thin, pale, dry, smooth, as well as poorly vascularized. Moreover, there is an increase in the number of collagen fibers and a decrease in the activity of acid and alkaline phosphatases. In addition, adipose tissue concentration in various parts of the mucous membrane is sometimes seen. Furthermore, 'palatal lipidophilia', a golden-yellow tint to the soft palate mucosa, is selectively evident. Senile epithelium is also more permeable for various harmful substances and more prone to mechanical injuries and the action of irritating agents with concurrent attenuation of wound healing processes. In addition, the susceptibility to microbial and fungal colonization of the epithelium increases with age. Both immunological and physical defense mechanisms of the mucous membrane are impaired, which decreases its regenerative capability and results in greater susceptibility to injuries. What is more, blood vessels of the oral mucosa are subject to regressive changes. They become delicate,

\begin{tabular}{l} 
^Corresponding author \\
e-mail: renata.chalas@umlub.pl \\
\hline
\end{tabular}

winding, frequently damaged with narrowing, dilations and arteriosclerotic changes $[7,12,17]$.

The aim of the study was to assess the condition of oral mucosa in seniors (individuals of both sexes who are over the age of 65) residing in Lublin's Nursing Homes or in home care.

\section{MATERIAL AND METHODS}

The study was conducted among 240 people aged 65 to $96-120$ women and 120 men. The patients were placed within 2 groups: the first group included 117 residents of the Lublin Nursing Homes (LNH); the second group included 123 seniors in home care. The patients in both groups were also grouped according to age, two being distinguished: I - 65 to 74; II - over 75. Each group included 120 people. All people revealed that had good living conditions and had good mobility. All gave informed consent for carrying out the study, which was approved by The Ethics Committee of the Medical University of Lublin, Poland.

The appraisal of oral mucosa condition was by way of a clinical examination. This included assessment of normal oral mucosa and of degree of pathological change, including the presence of: oral candidiasis (in susp.) - patients with 
the suspected candidiasis were then referred for mycological examination; atrophic glossitis, prosthetic inflammation of the oral mucosa; black, furry tongue; scalloped tongue; sublingual varices; inflammation of the corners of the mouth.

The obtained study results were submitted to statistical analysis according to the place of residence, age and gender, and are presented in Tables 1-6.

\section{RESULTS}

In the examined groups, the percentage of people who had pathological changes and the percentage of people with no changes were calculated (Tab. 1). Pathological changes of the oral mucosa were observed in $43.59 \%$ of all residents of Lublin Nursing Homes and in $34.96 \%$ of all seniors in home care. Statistically, no essential differences were evident in oral mucosa change between the investigated groups. However, oral mucosa degeneration was slightly more frequent among the LNH residents than in those in home care.

Table 1. Oral mucosa changes in the investigated groups as grouped by place of residence

\begin{tabular}{|l|c|c|c|}
\hline \multirow{2}{*}{ Examined group } & Yes & No & Total \\
\cline { 2 - 4 } & $\begin{array}{c}\text { Number of persons } \\
\%\end{array}$ & $\begin{array}{c}\text { Number of persons } \\
\%\end{array}$ & $\begin{array}{c}\text { Number of persons } \\
\%\end{array}$ \\
\hline \multirow{2}{*}{ Nursing homes } & 51 & 66 & 117 \\
\cline { 2 - 4 } & $43.59 \%$ & $56.41 \%$ & $100.00 \%$ \\
\hline \multirow{2}{*}{ Family homes } & 43 & 80 & 123 \\
\cline { 2 - 4 } & $34.96 \%$ & $65.04 \%$ & $100.00 \%$ \\
\hline \multirow{2}{*}{ Total } & 94 & 146 & 240 \\
\cline { 2 - 4 } & $39.17 \%$ & $60.83 \%$ & $100.00 \%$ \\
\hline
\end{tabular}

Statistical analysis: $\mathrm{Chi}^{2}=1,87 ; \mathrm{p}=0,17$

Statistical analysis has also revealed that in the LNH group, oral mucosa change occurred slightly more frequent in seniors over the age of $75-50.00 \%$ of all in the category, than in people aged $65-74-36.84 \%$ of the group total. These differences were not statistically significant (Tab. 2). Among the investigated in home care, oral mucosa change also occurred more frequently in people over the age of 75 $-45.00 \%$ of the group total, than in seniors aged $64-75-$ $25.40 \%$ of the total (Tab. 3). Grouped by gender, no essential differences were stated in oral mucosa changes between women residents of $\mathrm{LNH}-45.00 \%$ of the group total, and women in home care $-36.67 \%$ of the group total (Tab. 4 ). Similarly in men no statistically significant differences were seen in oral mucosa changes in LNH residents $-42.11 \%$ of the group total, and in home care residents $-33.33 \%$ (Tab. 5). Detailed studies revealed that in the LNH group, atrophic glossitis was more frequent $-49.02 \%$, candidiasis (in susp.) less frequent $-19.61 \%$, and far less frequent - prosthetic inflammation of the oral mucosa $-15.69 \%$, inflammation of the corners of the mouth $-5.88 \%$, black, furry tongue $5.88 \%$, scalloped tongue $-3.92 \%$, and sublingual varices $-1.96 \%$. Among seniors living in home care, $49.84 \%$ had atrophic glossitis, 25.58\% had candidiasis (in susp.), 16.28\% showed prosthetic inflammation of the oral mucosa, $9.30 \%$ evidenced sublingual varices and $4.65 \%$ revealed inflammation of the corners of the mouth (Tab. 6).
Table 2. Oral mucosa changes in nursing home residents, grouped by age

\begin{tabular}{|l|c|c|c|}
\hline \multirow{2}{*}{ Age } & Yes & No & Total \\
\cline { 2 - 4 } & $\begin{array}{c}\text { Number of persons } \\
\%\end{array}$ & $\begin{array}{c}\text { Number of persons } \\
\%\end{array}$ & $\begin{array}{c}\text { Number of persons } \\
\%\end{array}$ \\
\hline \multirow{2}{*}{$65-74$ years } & 21 & 36 & 57 \\
\cline { 2 - 4 } & $36.84 \%$ & $63.16 \%$ & $100.00 \%$ \\
\hline \multirow{2}{*}{75 years and more } & 30 & 30 & 60 \\
\cline { 2 - 4 } & $50.00 \%$ & $50.00 \%$ & $100.00 \%$ \\
\hline \multirow{2}{*}{ Total } & 51 & 66 & 117 \\
\cline { 2 - 4 } & $43.59 \%$ & $56.41 \%$ & $100.00 \%$ \\
\hline
\end{tabular}

Statistical analysis: $\mathrm{Chi}^{2}=2,06 ; \mathrm{p}=0,15$

Table 3. Oral mucosa changes in seniors living in home care (independently), grouped by age

\begin{tabular}{|c|c|c|c|}
\hline \multirow{2}{*}{ Age } & Yes & No & Total \\
\cline { 2 - 4 } & $\begin{array}{c}\text { Number of persons } \\
\%\end{array}$ & $\begin{array}{c}\text { Number of persons } \\
\%\end{array}$ & $\begin{array}{c}\text { Number of persons } \\
\%\end{array}$ \\
\hline \multirow{2}{*}{$65-74$ years } & 16 & 47 & 63 \\
\cline { 2 - 4 } & $25.40 \%$ & $74.60 \%$ & $100.00 \%$ \\
\hline \multirow{2}{*}{75 years and more } & 27 & 33 & 60 \\
\cline { 2 - 4 } & $45.00 \%$ & $55.00 \%$ & $100.00 \%$ \\
\hline \multirow{2}{*}{ Total } & 43 & 80 & 123 \\
\cline { 2 - 4 } & $34.96 \%$ & $65.04 \%$ & $100.00 \%$ \\
\hline
\end{tabular}

Statistical analysis: $\mathrm{Chi}^{2}=5,19 ; \mathrm{p}=0,02 *$

Table 4. Oral mucosa changes in women, grouped by place of residence

\begin{tabular}{|l|c|c|c|}
\hline \multirow{2}{*}{ Examined group } & Yes & No & Total \\
\cline { 2 - 4 } & $\begin{array}{c}\text { Number of women } \\
\%\end{array}$ & $\begin{array}{c}\text { Number of women } \\
\%\end{array}$ & $\begin{array}{c}\text { Number of women } \\
\%\end{array}$ \\
\hline \multirow{2}{*}{ Nursing homes } & 27 & 33 & 60 \\
\cline { 2 - 4 } & $45.00 \%$ & $55.00 \%$ & $100.00 \%$ \\
\hline \multirow{2}{*}{ Family homes } & 22 & 38 & 60 \\
\cline { 2 - 4 } & $36.67 \%$ & $63.33 \%$ & $100.00 \%$ \\
\hline \multirow{2}{*}{ Total } & 49 & 71 & 120 \\
\cline { 2 - 4 } & $40.83 \%$ & $59.17 \%$ & $100.00 \%$ \\
\hline
\end{tabular}

Statistical analysis: $\mathrm{Chi}^{2}=0,86 ; \mathrm{p}=0,35$

Table 5. Oral mucosa changes in men, grouped by place of residence

\begin{tabular}{|l|c|c|c|}
\hline \multirow{2}{*}{ Examined group } & Yes & No & Total \\
\cline { 2 - 4 } & $\begin{array}{c}\text { Number of men } \\
\%\end{array}$ & $\begin{array}{c}\text { Number of men } \\
\%\end{array}$ & $\begin{array}{c}\text { Number of men } \\
\%\end{array}$ \\
\hline \multirow{2}{*}{ Nursing homes } & 24 & 33 & 57 \\
\cline { 2 - 4 } & $42.11 \%$ & $57.89 \%$ & $100.00 \%$ \\
\hline \multirow{2}{*}{ Family homes } & 21 & 42 & 63 \\
\cline { 2 - 4 } & $33.33 \%$ & $66.67 \%$ & $100.00 \%$ \\
\hline \multirow{2}{*}{ Total } & 45 & 75 & 120 \\
\cline { 2 - 4 } & $37.50 \%$ & $62.50 \%$ & $100.00 \%$ \\
\hline
\end{tabular}

Statistical analysis: $\mathrm{Chi}^{2}=0,98 ; \mathrm{p}=0,32$

Table 6. Types of oral mucosa change, grouped by place of residence

\begin{tabular}{|l|c|c|c|c|}
\hline \multirow{2}{*}{ Pathological changes } & \multicolumn{2}{|c|}{ Nursing homes } & \multicolumn{2}{c|}{ Family homes } \\
\cline { 2 - 5 } & $\begin{array}{c}\text { Number of } \\
\text { persons }\end{array}$ & $\%$ & $\begin{array}{c}\text { Number of } \\
\text { persons }\end{array}$ & $\%$ \\
\hline $\begin{array}{l}\text { Candidiasis } \\
\text { (in susp.) }\end{array}$ & 10 & $19.61 \%$ & 11 & $25.58 \%$ \\
\hline $\begin{array}{l}\text { Prosthetic } \\
\text { inflamation of oral } \\
\text { mucosa }\end{array}$ & 8 & $15.69 \%$ & 7 & $16.28 \%$ \\
\hline Atrophic glossitis & 25 & $49.02 \%$ & 21 & $48.84 \%$ \\
\hline Black, furry tongue & 3 & $5.88 \%$ & 0 & $0.00 \%$ \\
\hline Scalloped tongue & 2 & $3.92 \%$ & 0 & $0.00 \%$ \\
\hline Sublingual varices & 1 & $1.96 \%$ & 4 & $9.30 \%$ \\
\hline $\begin{array}{l}\text { Inflammation of } \\
\text { the corners of the } \\
\text { mouth }\end{array}$ & 3 & $5.88 \%$ & 2 & $4.65 \%$ \\
\hline
\end{tabular}




\section{DISCUSSION}

Older age predisposes individuals to the development of pathological changes in the oral mucosa. The factors that contribute to their development are common diseases and the medications for these, decreased salivary secretion, general weakening of the immune system and changes within the tissues [7].

Pathological changes of the oral mucosa were observed in $43.59 \%$ of all Lublin Nursing Homes residents. The results are comparable to those obtained from the residents of Nursing Homes from Zabrze and Opole, where the percentage was $47.4 \%$ and $43 \%$ respectively. In both Zabrze and Opole, atrophic glossitis was seen most frequently (61\% and $58 \%$, respectively, of the group total), while inflammation of the corners of the mouth, pressure ulcers, sublingual varices and leukoplakia occurred quite frequently [10].

With regard to residents of Warsaw Nursing Homes, a higher percentage of residents showed changes in the glossal mucosa, than did those in our own studies (91\%). Scalloped tongue was also most frequently seen $-42 \%$ of the investigated, atrophic glossitis in 33\%, superficial glossitis in $23 \%$, furry tongue in $11 \%$, sublingual varices in $6 \%$, median rhomboid glossitis in 5\% and geographic tongue in 2\% [18]. Comparatively, among LNH residents, atrophic glossitis was observed in $49.02 \%$ of all examined, black, furry tongue in $5.88 \%$, scalloped tongue in $3.92 \%$, and sublingual varices in $1.96 \%$ of this study group.

Compared to our results, a lower percentage of seniors with oral mucosa change was noted in Wroclaw Nursing Home residents $(21 \%$ of the total), in Institutionalized Nursing Unit residents in Berlin, Germany (28.6\%) [6], as well as in the residents of Old People's Homes in Hannover and in private medical practice patients in Lohne, Germany [3]. Comparative figures are available from studies of Nursing Homes residents in Australia (16.8\%) [2], from Brazil (Taubaté) (19.5\%) [11], as well from England (33\% in Avon [4] and 40\% in West Hertfordshire [15]) and Iran $(45.6 \%)$ [14].

Regarding the use of dental prosthetics, prosthetic stomatopathies was noted very frequently among the residents of Nursing Homes in Szczecin and neighbouring environs who used removable dentures [16]. In our own studies, prosthetic inflammation of the oral mucosa was observed in $15.69 \%$ of all LHN seniors and in $16.28 \%$ of all home care seniors.

The longitudinal study by the Chair and Department of Conservative Dentistry of Jagiellonian University Medical College in Cracow of the state of the oral mucosa among Polish people treated between the years of 1961-1998 revealed that the most frequently occurring pathological changes were leukoplakia (18.03\% of the investigated), inflammatory changes (including prosthetic inflammation) $(15.34 \%)$, recurrent mouth ulcers $(9.53 \%)$, stomatodynia $(8.73 \%)$ as well as ulcerations $(8.21 \%$ of the study population) [8]. A similar analysis was performed in the specialist outpatient department in Wroclaw in the years 1992-2003. herein, in people over the age of 60 , candidiasis prevailed ( $25 \%$ of the investigated), while burning mouth syndrome was also observed $(21.7 \%)$, as was lichen planus $(16.7 \%)$, leukoplakia $(8.1 \%)$, post-traumatic changes (mainly prosthetic stomatopathies) (7\%) and recurrent mouth ulcers $(4.3 \%)$ [9].

The state of the oral mucosa is the reflection of changes in the human body. Therefore, a thorough dental examination frequently allows for the revelation of systemic diseases $[7,13]$. Diseases of the mucous membrane should be diagnosed and treated early, as some may develop into cancerous changes $[5,12,17]$. Therefore, regular dental check-ups are essential, especially in institutionalized nursing units, where it is typical to see long-term use of damaged prosthetic restorations which have harmful effect on the oral cavity tissues. Moreover, in such institutes, the access to dental care is often quite limited.

\section{CONCLUSIONS}

The condition of the oral mucosa of the examined seniors (aged over 65 years) from Lublin is unsatisfactory. Pathological changes in the oral mucosa were noted in nearly $40 \%$ of the test population, and was slightly more frequent in Lublin Nursing Homes residents than in people living independently in home care. In both groups, atrophic glossitis, candidiasis (in susp.) and stomatitis prothetica were most frequently noted.

\section{REFERENCES}

1. Bartczyszyn M., Jaczewski M., Tomalik I.: Evaluation of removable dentures' hygiene level and oral cavity mucous membrane condition among long-term care houses inhabitants in Wroclaw. Dent. Med. Probl., 42, 477, 2005.

2. Chalmers J.M. et al.: The prevalence and experience of oral diseases in Adelaide nursing home residents. Aust. Dent. J., 47, 123, 2002.

3. Frączak B., Lupa-Bühmann J., Sobolewska E.: Potrzeby leczniczoprotetyczne u seniorów w Niemczech. Rocz. PAM., 53, 134, 2007.

4. Frenkel H., Harvey I., Newcombe R.G.: Oral health care among nursing home residents in Avon. Gerodontology, 17, 33, 2000.

5. Kamińska-Pikiewicz K., Bachanek T, Chałas R. The incidence of oral dryness in people over 65 years living in Lublin. Curr. Issues Pharm. Med. Sci., 28, 250, 2015.

6. Knabe C., Kram P.: Dental care for institutionalized geriatric patients in Germany. J. Oral Rehabil., 24, 909, 1997.

7. Knychalska-Karwan Z. (2009): Stomatologia wieku podeszłego. Wydawnictwo Czelej, Lublin.

8. Knychalska-Karwan Z.: Zmiany chorobowe błony śluzowej jamy ustnej u 4752 chorych leczonych w Katedrze i Zakładzie Stomatologii Zachowawczej CM UJ w Krakowie w latach 1961-1998. Mag. Stomatol., 14, 10, 2004.

9. Konopka T., Mendak M.: Występowanie chorób błony śluzowej jamy ustnej u pacjentów poradni specjalistycznej we Wrocławiu w latach 1992-2003. Dent. Med. Probl., 41, 717, 2004.

10. Kowol-Damboń K. et al.: Stan błony śluzowej jamy ustnej u mieszkańców Domów Opieki Społecznej Zabrza i Opola. Czas. Stomatol., 48, 231, 1995.

11. Marchini L. et al.: Self-reported oral hygiene habits among institutionalised elderly and their relationship to the condition of oral tissues in Taubaté, Brazil. Gerodontology, 23, 33, 2006.

12. Pogorzelska-Stronczak B., Bubiłek-Bogacz A., Szporek B.: Niektóre stomatologiczne problemy zdrowotne osób w podeszłym wieku. Wiad. Lek., 54, 88, 2001.

13. Pregiel B. et al.: Stan zdrowia błony śluzowej jamy ustnej słuchaczy Uniwersytetu Trzeciego Wieku we Wrocławiu. Mag. Stomatol., 16, 72, 2006.

14. Rabiei M. et al.: Prevalence of oral and dental disorders in institutionalised elderly people in Rasht, Iran. Gerodontology, 27, $174,2010$. 
15. Simons D., Brailsford S., Kidd E.A.M., Beighton D.: Relationship between oral hygiene practices and oral status in dentate elderly people living in residential homes. Community Dent. Oral Epidemiol., 29, 464, 2001.

16. Stawska B.: Stomatologia geriatryczna - potrzeby, problemy i oczekiwania stomatologiczne pensjonariuszy domów pomocy społecznej. Rocz. PAM., 52, 89, 2006.
17. Triantos D.: Intra-oral findings and general health conditions among institutionalized and non-institutionalized elderly in Greece. J. Oral Pathol. Med., 34, 577, 2005.

18. Woś A. et al.: Ocena częstotliwości występowania zmian na języku u osób w wieku podeszłym w zależności od płci, chorób współistniejących i użytkowanych uzupełnień protetycznych. Nowa Stomatol., 3, 128, 2006. 